\title{
Perlindungan Hukum Bagi Pengguna Jasa Operator Seluler Atas Adanya Short Message Service (SMS) Spam
}

\author{
oleh
}

\author{
Hanum R Helmi*
}

\begin{abstract}
ABSTRAK
Pentingnya alat komunikasi sebagai kebutuhan untuk mengakses informasi dalam kehidupan sosial mengakibatkan menjamurnya penggunaan alat komunikasi telepon seluler. Untuk memudahkan pengaksesan serta pertukaran informasi antar sesame pengguna telepon seluler, maka operator seluler sebagai penyedia jasa layanan operator telah menyediakan berbagai macam fitur bagi pengguna telepon seluler. Bahkan saat ini telah banyak beredar telepon seluler yang dilengkapi dengan fitur-fitur canggih. Mulai dari layanan Short Message Service ( SMS) , Browsing, Chatting dan lain sebagainya. Namun fitur-fitur tersebut disalahgunakan dengan adanya SMS Spam yang dikirimkan ke telepon seluler para pengguna sehingga mengakibatkan ketidaknyamanan. Timbul permasalahan yang berkaitan dengan SMS Spam tersebut.
\end{abstract}

Kata kunci: informasi, telepon seluler, pengguna layanan telepon seluler, konsumen, operator seluler, SMS Spam, SMS Broadcast, Perlindungan konsumen, Tanggung gugat

\section{PENDAHULUAN}

Dalam era globalisasi seperti sekarang, kebutuhan akan mengakses suatu informasi adalah hal yang sangat penting dalam kehidupan sosial masyarakat. Informasi dibutuhkan masyarakat untuk mengetahui segala macam berita yang terkait dengan perkembangan zaman. Salah satu cara untuk mengakses informasi, masyarakat menggunakan berbagai alat komunikasi. Alat komunikasi yang seringkali digunakan oleh masyarakat untuk mengakses berbagai macam informasi adalah telepon seluler. Dari telepon seluler tersebut masyarakat dapat mengetahui berbagai macam informasi elektronik.
Dengan pentingnya informasi tersebut maka diperlukan suatu pengaturan mengenai hal hal yang berkaitan dengan informasi elektronik. Untuk itu lahirlah Undang-Undang nomor 11 tahun 2008 tentang Informasi dan Transaksi Elektronik (selanjutnya disebut dengan UU ITE) sebagai wujud perlindungan hukum dan kepastian hukum bagi pengguna informasi dan transaksi elektronik.

Seperti yang telah disebutkan di atas, bahwa telepon seluler selain sebagai alat komunikasi juga digunakan untuk

\footnotetext{
* Lembaga Bantuan Hukum Surabaya, hanum_ helmi@yahoo.com
} 
mengakses informasi. Operator seluler sebagai penyedia jasa layanan operator telah menyediakan berbagai macam fitur bagi pengguna telepon seluler. Bahkan saat ini telah banyak beredar telepon seluler yang dilengkapi dengan fitur-fitur canggih. Mulai dari layanan Short Message Service ( SMS) , Browsing, Chatting dan lain sebagainya.

Salah satu layanan operator yang sering digunakan masyarakat untuk berkomunikasi yaitu Short Message Service (SMS). Short Message Service ( SMS ) adalah suatu fasilitas untuk mengirim dan menerima suatu pesan singkat berupa teks melalui perangkat nirkabel, yaitu perangkat komunikasi telepon seluler, dalam hal ini perangkat nirkabel yang digunakan adalah telepon seluler ${ }^{1}$

Salah satu kelebihan dari SMS adalah biaya yang murah. Selain itu SMS merupakan metode store dan forward sehingga keuntungan yang didapat adalah pada saat telepon seluler penerima tidak dapat dijangkau, dalam arti tidak aktif atau diluar service area, penerima tetap dapat menerima SMS-nya apabila telepon selular tersebut sudah aktif kembali. Layanan SMS yang disediakan operator seluler selain berfungsi untuk berkomunikasi dengan orang lain, tetapi juga merupakan sarana yang sangat efektif untuk melakukan promosi, dan komunikasi karena akan langsung dibaca oleh pemilik telepon seluler. Dalam hal ini berarti SMS mempunyai multifunction.

Biasanya operator seluler dalam hal ini bekerja sama dengan Perusahaan

${ }^{1}$ http://ilmucomputer2.blogspot.com/pengertian sms diakses pada tanggal 10 Februari 2011
Penyedia Jasa layanan SMS Gateway untuk melakukan promosi. SMS Gateway adalah sebuah software atau aplikasi yang merubah proses mengolah SMS dari telepon selular ke Komputer PC/ Laptop, kemudian mengolah SMS seperti layaknya fitur di telepon selular, tetapi ada perbedaan dari segi fitur, fungsi yang bisa dibuat berdasarkan kebutuhan bisnis. Istilah SMS Gateway dalam Permenkominfo Nomor 1 Tahun 2009 tentang pengaturan mengenai SMS Premium dan SMS Broadcast disebut dengan SMS broadcast. Menurut Wikipedia,

"SMS gateway is the term used to describe a service transforming messages to mobilenetwork traffic from other media, or vice versa, allowing transmission or receipt of SMS messages with or without the use of a mobile phone. Typical use of a gateway would be to forward simple e-mail to a mobile phone recipient".

SMS Gateway tersebut biasa digunakan oleh operator untuk menawarkan layanan kepada pengguna telepon seluler seperti : untuk mengaktifkan Ringtone, Wallpaper, bahkan tawaran untuk mengikuti kuis dan lain sebagainya.

Akhir-akhir ini banyak permasalahan yang timbul mengenai layanan SMS Gateway. Berikut ini ada kutipan mengenai permasalahan mengenai layanan SMS Gateway :

Badan Regulasi Telekomunikasi Indonesia (BRTI) dan Yayasan Lembaga Konsumen Indonesia (YLKI) menemukan faktabahwasedikitnya 25jutadatapelanggan telekomunikasi di Indonesia sudah bocor. Angka ini mencapai 25 persen dari sekitar 
200 juta pelanggan telekomunikasi yang terdaftar. Fakta ini ditemukan dari sebuah iklan di koran harian nasional. Dalam iklan tersebut, perusahaan penyedia layanan SMS Gatewayitumenyebutkan 'Menyediakan 25 Juta data pelanggan seluler aktif, valid dan legal, seluruh Indonesia untuk SMS promo anda”. Sayangnya hingga saat ini belum diketahui siapa pihak yang bertanggung jawab membocorkan data tersebut. Tidak heran jika kemudian banyak pengguna seluler yang mengeluh telah dibombardir SMS promo yang cukup mengganggu. ${ }^{2}$

Penyediaan 25 juta SMS Gateway yang selama ini digunakan oleh operator seluler untuk mempromosikan fitur-fitur yang berguna bagi pelanggan operator seluler telah disalahgunakan oleh mereka yang tidak bertanggungjawab atas penyalahgunaan layanan SMS Gateway tersebut.

Selain permasalahan di atas, juga terdapat berbagai macam permasalahan yang timbul akibat adanya layanan SMS Gateway. Permasalahan tersebut yaitu mengenai adanya SMS Spam atau SMS sampah yang memenuhi ponsel pelanggan. Hal ini sangat meresahkan masyarakat. SMS spam ini ada yang berbentuk penipuan atau penawaran produk yang digunakan oleh perorangan atau kelompok.

Adanya SMS Spam atau sampah ini dilatarbelakangi adanya besarnya bonus sms lintas operator per hari. Berdasarkan catatan di lapangan terdapat dua nomor operator yang sering digunakan untuk mengirimkan

${ }^{2}$ http://techno.okezone.com/ data pelanggan bocor brti telah minta klarifikasi dikunjungi pada tanggal 26 Januari 2011 penawaran KTA. Kedua operator itu adalah Axis dan Tri. Axis memiliki penawaran gratis 10 ribu SMS per hari, sedangkan Tri 100 ribu SMS per hari. ${ }^{3}$

Adanya permasalahan-permasalahan di atas, jika dikaitkan dengan peraturan perundang-undangan yang terkait dan berlaku di Indonesia baik mengenai peraturan mengenai Undang-Undang Nomor 36 Tahun 1999 tentang Telekomunikasi dan Undang-Undang Nomor 11 Tahun 2008 tentang Informasi dan Transaksi Elektronik maupun peraturan-peraturan lainnya maka terdapat pelanggaran-pelanggaran yang telah dilakukan. Pelanggaran tersebut yaitu mengenai SMS Spam yang merugikan konsumen. SMS Spam yang dikirimkan ke pelanggan tanpa izin si pemilik nomor dan si pengirim pun tidak mengantongi izin dari Badan Regulasi Telekomunikasi Indonesia (selanjutnya disebut BRTI) ini melanggar Permenkominfo No 01/2009 tentang Penyelenggaraan Jasa Pesan Premium dan Pengiriman Jasa Pesan Singkat.

Dalam kaitannya dengan adanya SMS Spam yang seringkali dikirimkan oleh pihak-pihak yang tidak bertanggung jawab terdapat berbagai macam keluhan dari sebagian besar masyarakat yang menerima SMS Spam tersebut. Para pengguna jasa operator seluler sering merasa terganggu dengan adanya SMS Spam baik yang menggunakan modus penipuan lewat permintaan pulsa, sms berhadiah, dan sebagainya. Tidak sebatas keluhan, para pengguna operator telepon seluler juga

${ }^{3} \mathrm{http} / / /$ doniismanto.wordpress.com/ sms spam simalakama strategi pemasaran dikunjungi pada tangal 26 Agustus 2010 
telah banyak menderita kerugian akibat adanya SMS Spam tersebut. Kerugian yang dialami oleh pengguna jasa operator berupa kerugian secara materiil maupun immateriil yaitu terganggunya kenyamanan dalam penggunaan jasa operator seluler.

\section{Karakteristik mengenai SMS Spam}

Dalam rangka mencapai untung yang setinggi-tingginya itu, para produsen/pelaku usaha harus bersaing antar pelaku usaha satu dengan pelaku usaha lainnya. Antara Pihak operator satu dengan yang lainnya bersaing untuk mencapai keuntungan yang sebesarbesarnya. Seringkali dalam persaingan yang dilakukan oleh pelaku usaha tersebut dapat menimbulkan kerugian bagi konsumen. Salah satunya dengan cara mengeluarkan produk SMS broadcast.

Layanan SMS yang disediakan oleh operator mempunyai kelebihan, yaitu biaya yang murah. Selain itu SMS merupakan metode store dan forward sehingga keuntungan yang didapat adalah pada saat telepon seluler penerima tidak dapat dijangkau, dalam arti tidak aktif atau diluar service area, penerima tetap dapat menerima SMS-nya apabila telepon seluler tersebut sudah aktif kembali.

Layanan SMS yang disediakan oleh operator saat ini mempunyai multifunction. Selain untuk menyediakan fasilitas bagi pengguna telepon seluler untuk mengakses berbagai macam informasi, tetapi juga sebagai sarana bagi pihak operator sendiri untuk melakukan SMS broadcast yang tujuannya untuk menawarkan berbagai macam promosi. SMS broadcast adalah SMS yang dikirim oleh operator yang ditujukan ke banyak tujuan. SMS broadcast tersebut berisi berbagai macam penawaran. Misalnya penawaran untuk mengikuti kuis, mengaktifkan ringtone, wallpaper sampai dengan penawaran yang bersifat pribadi seperti penawaran Kredit Tanpa Agunan (KTA).

SMS broadcast yang dikirim oleh pihak operator umumnya bersifat komersiil. Konsumen seringkali dirugikan dengan adanya SMS broadcast tersebut, karena SMS tersebut tidak dikehendaki oleh konsumen. Hal inilah yang akhir-akhir ini sering disebut dengan SMS Spam. SMS Spam adalah suatu penerimaan pesan singkat dari penyedia jasa layanan operator seluler, dimana isi dalam SMS tersebut tidak dikehendaki oleh pengguna jasa operator dan dilakukan secara terus menerus tanpa ijin pengguna jasa operator seluler.

Dikatakan Spam karena SMS tersebut isinya tidak dikehendaki oleh konsumen. Contohnya,kita sebagai pengguna seluler baik menggunakan operator apapun pasti pernah mendapatkan SMS dari operator bahkan sering, isi SMS tersebut terkadang bahkan hampir tidak penting bagi kita, seperti promosi iklan, kuis-kuis, atau yang paling sering setiap kita selesai mengecek pulsa atau setelah menelpon rekan, akan ada kiriman SMS dari operator sekedar menawarkan iklan-iklan atau ring back tone.

SMS Spam yang dikirimkan kepada pelanggan tanpa izin si pemilik nomor dan 
si pengirim pun tidak mengantongi izin dari Badan Regulasi Telekomunikasi Indonesia (selanjutnya disebut BRTI) ini melanggar Permenkominfo No 01/2009 tentang Penyelenggaraan Jasa Pesan Premium dan Pengiriman Jasa Pesan Singkat.

Sebagai konsumen, maka pengguna jasa operator seluler mempunyai hakhak yang dilindungi oleh undang-undang, khususnya Undang-Undang Nomor 8 Tahun 1999 tentang Perlindungan Konsumen. Hak-hak konsumen tersebut diatur pada Pasal 4, salah satunya adalah hak atas kenyamanan, keamanan, dan keselamatan dalam mengkonsumsi barang dan/atau jasa. Dengan adanya hak tersebut, maka pengguna jasa operator seluler mempunyai hak seperti yang telah disebutkan dalam Pasal 4 UU Perlindungan Konsumen.

SMS broadcast oleh pihak operator diduga melanggar salah satu ketentuan dalam Undang-Undang Nomor 36 Tahun 1999 tentang Telekomunikasi. Pada Pasal 21 Undang-Undang Telekomunikasi menyebutkan bahwa penyelenggara komunikasi dilarang melakukan kegiatan usaha penyelenggaraan telekomunikasi yang bertentangan dengan kepentingan umum, kesusilaan, keamanan dan ketertiban umum.

Adanya permasalahan-permasalahan mengenai SMS Spam yang merugikan konsumen tersebut mengundang perhatian pemerintah untuk segera menyelesaikan permasalahan dengan langkah preventif maupun represif. Yang dimaksud dengan preventif adalah bersifat mencegah agar tidak terjadi. Jadi perlindungan hukum preventif adalah perlindungan hukum dalam peraturan perundang-undangan yang bersifat mencegah kerugian masyarakat, dalam hal ini adalah konsumen. Sedangkan yang dimaksud dengan represif adalah bersifat menekan dan mengekang. Jadi, yang dimaksud dengan perlindungan hukum represif adalah perlindungan hukum dalam bentuk upaya hukum yang dapat dilakukan konsumen yang merasa dirugikan, agar yang bersangkutan mendapatkan kembali apa yang seharusnya menjadi haknya.

Mengenai SMS Spam, tidak ada ketentuan hukum di Indonesia yang mengatur secara khusus tentang keberlakuan SMS Spam. SMS Spam ini dapat dikaitkan dengan beberapa ketentuan-ketentuan yang relevan yang dapat dipergunakan sebagai bentuk perlindungan hukum terhadap adanya SMS Spam. Adapun ketentuanketentuan perundangan-undangan yang berkaitan dengan upaya perlindungan hukum konsumen atas adanya SMS Spam adalah Undang-Undang no.8 tahun 1999 tentang Perlindungan Konsumen, Peraturan Menteri Komunikasi dan Informasi Nomor 1 Tahun 2009 mengenai SMS premium dan SMS broadcast.

\section{Tanggung gugat pelaku usaha}

Produsen sebagai pelaku usaha mempunyai tugas dan kewajiban untuk ikut serta menciptakan dan menjaga iklim usaha yang sehat untuk menunjang bagi pembangunan perekonomian nasional secara keseluruhan. Karena itu kepada produsen dibebankan tanggung gugat atas 
pelaksanaan tugas dan kewajiban itu, yaitu melalui penerapan norma-norma hukum, kepatutan dan menjunjung tinggi kebiasaan yang berlaku di kalangan dunia usaha. ${ }^{4}$

Kewajiban pelaku usaha untuk senantiasa beritikad baik dalam melakukan kegiatannya (Pasal 7 angka 1) berarti bahwa pelaku usaha ikut bertanggung jawab untuk menciptakan iklim yang sehat dalam berusaha demi menunjang pembangunan nasional. Banyak ketentuan di dalam Undang-Undang Perlindungan Konsumen ini yang bermaksud mengarahkan pelaku usaha untuk berperilaku sedemikian rupa dalam rangka menyukseskan pembangunan ekonomi nasional, khususnya di bidang usaha. Atas setiap pelanggaran yang dilakukan oleh produsen maka kepadanya dikenakan sanksi hukum, baik sanksi administratif maupun sanksi pidana. Pemberian sanksi ini penting mengingat bahwa menciptakan iklim usaha yang sehat membutuhkan keseriusan dan ketegasan.

Sesuai dengan ketentuan yang telah disebutkan dalam Pasal 7 Undang-undang Perlindungan Konsumen (selanjutnya disingkat UUPK), maka pelaku usaha yang tidak memenuhi kewajibannya dapat dituntut secara hukum untuk mengganti segala kerugian yang timbul sehubungan dengan tidak dipenuhinya kewajiban itu. Pelaku usaha dalam hal ini penyedia jasa layanan operator seluler mempunyai kewajiban memberikan kompensasi atau ganti rugi atas kerugian konsumen akibat adanya SMS broadcast yang melanggar hak

${ }^{4}$ Janus Sidabalok, Hukum Perlindungan Konsumen di Indonesia, (edisi 4, Citra Aditya Bakti, 2006) hal.93. konsumen yaitu hak atas kenyamanan.

Menurut pasal 19 ayat (1) UUPK disebutkan bahwa pelaku usaha bertanggungjawab memberikan ganti rugi atas kerusakan, pencemaran, dan/atau kerugian konsumen akibat mengonsumsi barang dan/atau jasa yang dihasilkan atau diperdagangkan. Sistem tanggung gugat yang terdapat pada UUPK secara garis besar merupakan sistem tanggung gugat kesalahan, dimana diperlukan adanya pembuktian unsur kesalahan dan menggunakan asas pembalikan beban pembuktian. Tanggung gugat kesalahan dengan pembalikan beban pembuktian yang dianut UUPK, mengandung makna bahwa yang berkewajiabn untuk membuktikan ada tidaknya unsur kesalahan adalah pihak pelaku usaha. Bilamana pelaku usaha tidak dapat membuktikan bahwa ia tidak bersalah atau ia telah terbukti melakukan kesalahan, maka pelaku usaha berkewajiban untuk memberukan ganti rugi pada konsumen.

Sistem tanggung gugat kesalahan dengan pembalikan beban pembuktian ini secara eksplisit dirumuskan dalam Pasal 28 UUPK “ Pembuktian terhadap ada tidaknya unsur kesalahan dalam gugatan ganti rugi sebagaimana dimaksud dalam pasal 19, pasal 22, pasal 23 merupakan beban dan tanggung jawab pelaku usaha." Tanggung gugat kesalahan dengan pembalikan beban pembuktian ini merupakan salah satu bentuk tanggung gugat yang dipertajam, dengan sistem ini posisi konsumen yang dirugikan akan diperkuat dengan tidak mengabikan unsur-unsur tanggung gugat kesalahan. 
Hubungan Hukum Antara Perusahaan Penyedia Jasa Layanan Operator Seluler Dengan Pengguna Layanan Operator Seluler dan Perusahan Penyedia Jasa Layanan SMS Broadcast

Mengenai hubungan hukum yang terjalin antara pelaku usaha dalam hal ini penyedia jasa layanan operator seluler dengan konsumen penguna operator seluler adalah hubungan non kontraktual. Artinya, pelaku usaha tidak mempunyai hubungan kontraktual secara langsung dengan konsumen. Pelaku usaha memproduksi kartu perdana untuk dijual kepada konsumen melalui distributor. Kartu perdana tersebut dimanfaatkan oleh konsumen sesuai dengan layanan yang diberikan oleh pelaku usaha layanan operator seluler. Distributor dalam hal ini hanya sebatas menjual produk yang diproduksi oleh pelaku usaha layanan operatorseluler. Selanjutnyayangmelakukan proses teknis mengenai kegunaan atas kartu perdana tersebut adalah pihak penyedia jasa layanan operator seluler. Jadi dalam hal ini, pihak konsumen tidak mempunyai ikatan perjanjian secara langsung dengan pihak pelaku usaha tersebut.

Meski demikian, untuk melindungi kepentingan konsumen yang tidak terikat dalam suatu hubungan kontraktual, konsumen tetap bisa mengajukan gugatan dengan dasar gugatan negligence, implied warranty, perbuatan melanggar hukum (yang memakai prinsip keasalahan maupun dengan prinsip resiko).

Sedangkanperjanjianbisnisyangterjalin antara pihak operator dengan perusahaan penyedia jasa layanan SMS broadcast merupakan perjanjian kontraktual. SMS broadcast yang dikirim kepada pengguna operator seluler merupakan hasil transaksi business to business yang dilakukan oleh pihak operator seluler dengan perusahaan yang melayani bisnis SMS broadcast.

Pihak operator memberikan modal berbentuk pulsa untuk menyebarkan SMS broadcast kepada perusahaan tersebut, sedangkan perusahaan hanya menyediakan alat untuk menyebar SMS broadcast tersebut.

\section{Hubungan Hukum Antara Perusahaan Penyedia Jasa Layanan SMS Broadcast Dengan Konsumen}

Dalam hal hubungan hukum antara konsumen dengan perusahaan penyedia jasa layanan SMS broadcast, antara keduanya tidak mempunyai perikatan secara khusus. Karena perusahaan penyedia jasa layanan SMS broadcast tersebut hanya bekerjasama dengan penyedia jasa layanan operator seluler.Penyediajasalayananoperatorseluler melakukan perjanjian secara kontraktual dengan perusahaan yang bergerak di bidang layanan SMS broadcast untuk melakukan bisnis pengiriman SMS broadcast kepada konsumen. Sehingga pelaku usaha yang bergerak di bidang SMS broadcast tersebut sama sekali tidak mempunyai hubungan kontraktual. 
Dasar Gugatan yang Dapat Diajukan Oleh Konsumen yang Dilanggar Hakhaknya

Terdapat dua dasar gugatan yang dapat diajukan oleh konsumen yang dilanggar hakhaknya yakni gugatan berdasarkan perbuatan melanggar hukum dan gugatan berdasarkan UUPK. Yang pertama akan dibahas adalah gugatan berdasarkan perbuatan melanggar hukum.

Menurut Gunawan Widjaja dan Ahmad Yani baik perjanjian yang dibuat dan disepakati oleh para pihak maupun yang dibuat oleh pembuat undang-undang, keduanya membuat perikatan diantara para pihak yang membuatnya. $^{5}$

BerdasarkankasusmengenaiSMSSpam tersebut, konsumen tidak terikat perjanjian atau tidak mempunyai hubungan kontraktual dengan pelaku usaha (pihak operator seluler maupun perusahaan penyedia jasa layanan SMS broadcast). Namun tidak begitu saja pelaku usaha tersebut bebas dari tanggung jawab. Karena itu, bila seseorang konsumen menderita kerugian akibat produk yang cacat dan ingin menuntut pihak produsen/ pelaku usaha, maka jalan hukum yang dapat ditempuh yaitu berdasarkan perbuatan melanggar hukum yakni yang diatur dalam Pasal 1365 BW.

Mengenai perbuatan melanggar hukum, hal tersebut diartikan dengan berbuat atau tidak berbuat yang bertentangan dengan kewajiban hukum pelaku, melanggar hak orang lain, bertentangan dengan kesusilaan

\footnotetext{
${ }^{5}$ Gunawan Widjaja dan Ahmad Yani, Hukum Tentang Perlindungan Konsumen, (edisi 3, Gramedia Pustaka Utama, 2001), 30-31
}

atau bertentangan dengan kecermatan yang harus diindahkan dalam lalu lintas masyarakat terhadap diri dan barang orang lain.

Bila dikaitkan dengan permasalahan mengenai SMS Spam, perbuatan melanggar hukum yang dilakukan oleh pihak operator dibuktikan dengan adanya keluhan-keluhan konsumen yang timbul oleh adanya SMS Spam. Pihak operator dengan sengaja mengirimkan SMS broadcast berupa penawaran yang bersifat komersiil. SMSSMS yang pengirimannya tidak dikehendaki oleh konsumen tersebut telah mengganggu kenyamanan konsumen.

Dalam Pasal 7 UUPK telah diatur mengenai kewajiban-kewajiban pelaku usaha yang salah satunya adalah harus memerhatikan kenyamanan konsumen. Apabila pelaku usaha melanggar ketentuan yang diatur oleh undang-undang, maka atas pelanggaran yang dilakukan oleh pelaku usaha tersebut mewajibkan pelaku usaha untuk mengganti kerugian yang diderita oleh konsumen.

Penerapan tanggung gugat pelaku usaha berdasarkan Pasal 1365 BW ini, mewajibkan pihak penderita (penggugat) membuktikan adanya hubungan kausal antara perbuatan dan kerugian. Pembuktian demikian ini sebagai azas "tanggung gugat kesalahan".

Pemenuhan ganti rugi konsumen bergantung pada keberhasilan pembuktiannya. Konsumen harus membuktikan adanya kesalahan yang dilakukan oleh pelaku usaha. Dalam hal 
pemenuhan ganti rugi oleh pelaku usaha, pelaku usaha yang bertanggung gugat atas kerugian yang diderita konsumen ini adalah pihak pelaku usaha dari penyedia jasa layanan operator seluler karena konsumen membeli produk kartu perdana tersebut dari pihak operator seluler.

Sedangkan yang kedua adalah gugatan berdasarkan UUPK. Sesuai dengan ketentuan yang telah disebutkan dalam Pasal 7 UUPK, pelaku usaha yang tidak memenuhi kewajibannya dapat dituntut secara hukum untuk mengganti segala kerugian yang timbul sehubungan dengan tidak dipenuhinya kewajiban itu.

Pelaku usaha dalam hal ini penyedia jasa layanan operator seluler mempunyai kewajiban memberikan kompensasi atau ganti rugi atas kerugian konsumen akibat adanya SMS broadcast yang melanggar hak konsumen yaitu hak atas kenyamanan. Konsumen dapat mengajukan gugatan sesuai dengan kerugian yang dideritanya.

Pihak operator dengan sengaja mengirimkan SMS broadcast berupa penawaran yang bersifat komersiil. SMSSMS yang pengirimannya tidak dikehendaki oleh konsumen tersebut telah mengganggu kenyamanan konsumen. Dalam hal ini pihak operator telah melakukan pelanggaran terhadap hak konsumen, yaitu hak atas kenyamanan. Atas pelanggaran yang dilakukan oleh pelaku usaha, kepadanya dapat dijerat dengan dasar perbuatan melanggar hukum, sehingga konsumen dapat menuntut ganti rugi.

Adapun bentuk ganti rugi sebagaimana diatur dalam pasal 19 ayat (2) UUPK yaitu pengembalian uang, penggantian barang dan/atau jasa yang setara nilainya, perawatan kesehatan, atau pemberian santunan yang sesuai dengan peraturan perundangundangan.

\section{Penyelesaian Sengketa Konsumen Atas Tidak Dipenuhinya Hak Konsumen}

Penyelesaian sengketa konsumen dapat dilakukan melalui pengadilan atau di luar pengadilan. Dalam UUPK, penyelesaian sengketa konsumen diatur dalam Bab XPasal 45-48. Pasal 45 ayat (2) UUPK menyebutkan bahwa penyelesaian sengketa konsumen dapat ditempuh melalui pengadilan atau di luar pengadilan berdasarkan pilihan sukarela para pihak yang bersengketa. Dengan demikian pada hakikatnya cara penyelesaian sengketa konsumen berdasarkan UUPK dapat digunakan 2 jalur, yaitu jalur litigasi ( melalui lembaga peradilan) dan jalur non litigasi.

\section{a. Jalur Litigasi ( melalui lembaga peradilan)}

Dalam hukum perlindungan konsumen, secara umum proses beracara dalam menyelesaikan sengketa konsumen dan pelaku usaha mengenal adanya tiga macam gugatan, yaitu small claim, class action, legal standing dan proses beracara yang dilakukan oleh lembaga tertentu yakni Lembaga Perlindungan Konsumen Swadaya Masyarakat yang diatur dalam PP Nomor 59 Tahun 2001.

Small claim dapat diartikan sebagai peradilan kilat dengan hakim tungal, 
prosedur sederhana, tidak ada keharusan menggunakan pengacara, tidak ada upaya banding dan biaya ringan. Sedangkan Class action atau gugatan pewakilan kelompok diakomodir dalam pasal 46 ayat (1) huruf b UUPK.

\section{b. Jalur non-litigasi (Badan Penyelesaian Sengketa Konsumen - BPSK dan Alternative Dispute Resolution)}

BPSK adalah lembaga yang memerika sengketa konsumen, yang bekerja seolaholah sebagai sebuah pengadilan. BPSK tidak menyelesaikan sengketa konsumen dengan jalan damai, tetapi memeriksa sengketa berdasarkan hukum. Artinya, BPSK dalam menjalankan perannya dalam penyelesaian sengketa tetap berpegang teguh pada ketentuan Undang- Undang yang berlaku. BPSK dibentuk pemerintah di tiap-tiap daerah untuk menyelesaikan sengketa di luar pengadilan. Tugas dan wewenang BPSK disebutkan dalam Pasal 52 UUPK, yaitu :

a. Melaksanakan penanganan dan penyelesaian sengketa dengan cara melalui mediasi atau arbitrase atau konsiliasi;

b. Memberikan konsultasi perlindungan konsumen;

c. Melakukan pengawasan terhadap pencantuman klausula baku;

d. Melaporkan kepada penyidik apabila terjadi pelanggaran ketentuan dalam Undang-Undang ini;

e. Menerima pengaduan baik tertulis maupun tidak tertulis, dari konsumen tentang terjadinya pelanggaran terhadap perlindungan konsumen;

f. Melakukanpenelitiandan pemeriksaan sengketa perlindungan konsumen;

g. Memanggil dan menghadirkan saksi, saksi ahli dan/atau setiap orang yang dianggap mengetahui pelanggaran terhadap Undang-Undang ini;

h. Meminta bantuan penyidik untuk menghadirkan pelaku usaha, saksi, saksi ahli dan/atau setiap orang sebagaimana dimaksud dalam huruf g, yang tidak bersedia memenuhi panggilan BPSK;

i. Mendapatkan, meneliti dan/atau menilai surat, dokumen atau alat lain guna penyelidikan dan/atau pemeriksaan;

j. Memutuskan ada atau tidak adanya kerugian di pihak konsumen;

k. Memberikan putusan kepada pelaku usaha yang melakukan pelanggaran terhadap perlindungan konsumen;

1. Menjatuhkan sanksi administratif kepada pelaku usaha yang melanggar ketentuan Undang - Undang ini.

Dalam penyelesaian sengketa antara konsumen dengan pelaku usaha, jika tidak ada kesepakatan saat ditempuh dalam jalur damai atau tidak sepakat atas hakhak konsumen yang dilanggar oleh pelaku usaha, ada tiga tata cara penyelesaian sengketa berdasarkan KMPP 350/2001 sebagai berikut :

a. Konsiliasi 
Dalam KMPP350/2001 Pasal 1 angka 9 menjelaskan bahwa konsiliasi adalah proses penyelesaian sengketa konsumen diluar pengadilan dengan perantara BPSK untuk mempertemukan pihak yang bersengketa, dan penyelesaiannya diserahkan pada para pihak. Penyelesaian dengan cara ini dilakukan sendiri oleh para pihak yang bersengketa yaitu konsumen dan pelaku usaha dengan didampingi oleh Majelis dalam upaya penyelesaiannya. Majelis berupaya untuk mendamaikan para pihak yang bersengketa dan menjelaskan peraturan perundang-undangan dibidang perlindungan konsumen. Kepada konsumen dan pelaku usaha yang bersengketa diberi kesempatan yang sama untuk menjelaskan hal-hal yang disengketakan. Dalam konsiliasi ini Majelis hanya bertindak pasif sebagai Konsiliator (Pasal 5 ayat 1 KMPP 350/2001) dalam proses penyelesaian sengketa sedangkan keputusan atau kesepakatan penyelesaian sengketa diserahkan kepada para pihak yang bersengketa, keputusan tersebut tergantung dengan kesukarelaan para pihak.

b. Mediasi

Penyelesaian sengketa dengan cara mediasi berdasarkan KMPP 350/2001 Pasal 1 angka 10 menjelaskan bahwa mediasi merupakan proses penyelesaian sengketa konsumen diluar pengadilan dengan perantara BPSK sebagai penasehat dan penyelesaiannya diserahkan pada para pihak yaitu konsumen dan pelaku usaha. Penyelesaian dengan cara ini dilakukan sendiri oleh konsumen dan pelaku usaha yang bersengketa dengan didampingi oleh majelis yang bertindak aktif (Pasal 5 ayat 2 KMPP 350/2001). Dengan maksud Majelis bertindak sebagai Mediator dengan memberikan nasehat, petunjuk saran dan upaya-upaya lain dalam menyelesaikan sengketa. Namun keputusan atau kesepakatan dalam penyelesaian sengketa tetap diserahkan sepenuhnya kepada konsumen dan pelaku usaha yang bersengketa kemudian dituang dalam perjanjian tertulis antara para pihak yang bersengketa.

Penyelesaian sengketa melalui mediasi maupun konsiliasi, sepenuhnya diserahkan kepada pihak yang bersengketa untuk memperoleh kesepakatan dalammenentukan baik dalam bentuk maupun jumlah ganti rugi yang diterima oleh konsumen. Kesepakatan ini dituangkan dalam perjanjian tertulis dan ditandatangani oleh kedua belah pihak yang bersengketa. Hal ini dimaksudkan sebagai bukti untuk pembuatan berita acara oleh panitera BPSK.

\section{c. Arbitrase}

Lain dengan cara mediasi dan konsiliasi berdasarkan pasal 1 angka 11 KMPP 350/2001, Arbitrase adalah proses penyelesaian sengketa konsumen di luar pengadilan yang dalam hal ini pihak konsumen danpelakuusahayangbersengketa menyerahkan sepenuhnya penyelesaian kepada BPSK. Dalam penyelesaian sengketa konsumen di luar pengadilan melalui cara arbitrase, pelaksanaannya berbeda dengan cara penyelesaian sengketa melalui cara konsiliasi maupun mediasi. Melalui cara ini, majelis bertindak aktif untuk mendamaikan para pihak yang bersengketa bilamana 
tidak tercapai kesepakatan. Yang dilakukan pertama kali adalah dengan memberikan penjelasan kepada konsumen dan pelaku usaha yang bersengketa tentang perihal peraturan perundang-undangan dibidang perlindungan konsumen serta diberikan kesempatan yang sama kepada konsumen dan pelaku usaha untuk menjelaskan halhal yang dipersengketakan. Melalui cara ini keputusan/kesepakatan dalam penyelesaian sengketa ini sepenuhnya menjadi kewenangan majelis yang dibentuk BPSK tersebut.

\section{Kesimpulan}

SMS broadcast yang dikirim oleh penyedia jasa layanan operator seluler kepada pengguna jasa layanan operator seluler tidak sesuai dengan aturan yang berlaku. Karena SMS yang pengirimannya tidak dikehendaki oleh konsumen tersebut seringkali menimbulkan kerugian. Sehingga SMS broadcast tersebut seringkali disebut dengan SMS Spam atau SMS sampah.

Perusahaan penyedia jasa layanan operator seluler wajib bertanggung gugat atas kerugian yang diderita konsumen akibat kelalaian yang dilakukan. Pihak pelaku usaha telah melanggar kewajiban yang seharusnya ditaati oleh setiap pelaku usaha dalam menjalankan kegiatan usahanya. Dalam hal ini, pengguna jasa layanan operator seluler yang dilanggar hak-haknya dapat mengajukan gugatan berdasarkan perbuatan melanggar hukum kepada pelaku usaha melalui jalur litigasi (melalui lembaga peradilan). Selain itu konsumen juga mengajukan gugatan melalui jalur non- litigasi, melalui BPSK dan penyelesaian dengan jalan damai.

\section{Daftar Bacaan}

Yani, Ahmad, Gunawan Widjaja, Hukum Tentang Perlindungan Konsumen, PT Gramedia Pustaka Utama, Jakarta, 2001.

M.Zen, Patra, Panduan Bantuan Hukum di Indonesia, Yayasan Obor Indonesia, Jakarta, 2009

Marzuki, Peter Mahmud, Penelitian Hukum, Kencana Prenda Media, Jakarta, 2005.

Sidabalok, Janus, Hukum Perlindungan Konsumen di Indonesia, Citra Aditya Bakti, Bandung, 2006.

Mertokusumo, Sudikno, Mengenal Hukum, Liberty, Yogyakarta, 1986.

Djojodirdjo, Moegni, Perbuatan Melawan Hukum, Pradnya Paramita, Jakarta, 1979.

Sidharta, Hukum Perlindungan Konsumen Indonesia, Grasindo, 2000.

Miru, Ahmad, Hukum Prrlindungan Konsumen, RajaGrafindo Persada, Jakarta, 2004.

Burgerlijk Wetboek (BW) terjemahan Prof.R.Subekti

- $\quad$ Undang-Undang Nomor 8 tahun 1999 tentang Perlindungan Konsumen Undang-Undang Nomor 11 Tahun 2008 tentang Informasi dan Transaksi Elektronik

- Undang-Undang Nomor 36 Tahun 1999 tentang Telekomunikasi

- Peraturan Menteri Komunikasi dan Informasi Nomor 01 Tahun 2009 tentang tentang Penyelenggaraan Jasa Pesan Premium dan Pengiriman Jasa Pesan Singkat. 